\title{
The role of Libraries in Cultural Centres Abroad: an insight
}

\begin{abstract}
This research paper sets up a typology of libraries managed by cultural centres abroad. Nearly 2,200 libraries linked to a dozen of different cultural organizations provide not only traditional services such as loan and access to printed and audiovisual materials but they also approach local citizens, offering help and services in matters of education, literacy, cooperation, social issues or development. These actions may fit under the label of cultural diplomacy actions. This paper analyses the relevance of those cultural centres and offers a classification through a table including networks of institutions of the thirty most significant cultural centres worldwide.
\end{abstract}

Key words: Cultural centres, Cultural diplomacy, public services, libraries, libraries abroad, cooperation.

\section{Introduction}

Currently, cultural activities have become increasingly present in diplomatic and international relations. These actions have become an alternative to military operations. Cultural activities are perceived positively as they offer economic advantages.

Since the late Nineteenth century, many countries started to create their own network of cultural institute centres throughout the world. They aimed to share their knowledge as well as their language and culture in the geographical areas abroad their own borders.

In this sense, cultural propaganda as a key tool of public diplomacy was reinforced during the Cold War, with first class actors such as the United States, the Soviet Union and Eastern Europe countries (Malissen, 2005). The existing rivalry between the different blocks promoted the relevance of those new party agents. During this period, the term "cultural cold war" flourished due to the battle of ideas of European intellectuals against the Communist ideology (Niño, 2013).

Every cultural organization has always been considered a first priority in the bilateral relations and the specific needs of the host country or area. To support the success of these actions, cultural centres have facilities, and among them feature libraries, the object of study of this paper. 


\section{The Creation of Cultural Centres abroad}

This section offers a brief summary of the emergence of cultural centres abroad. Late Nineteenth century France marked a new concept with the establishment of cultural centres in foreign countries. France opened the first cultural centre in 1883, the "Alliance Française" or "French Alliance". A new "tool" of culture was introduced as a focal point of dialogue between countries and regions, as a resource for peace and equitable development and, last, as a tool of public diplomacy too.

This new mechanism of international promotion of French culture offered opened physical spaces to citizens, while maintaining the objective of propagation of French language and culture in colonies and former colonies. Over the years, this generated an increasingly visible duality between the external promotion of culture, support, and local cooperation on one hand, while a search for benefits or profits to the country of origin on the other (Cortier, 1998).

During the Twentieth century, other Western countries followed this initiative and created their own cultural institutions. These centres introduced their best interests to local citizens of the host countries, providing a channel to influence them.

Emulating the Alliance Francaise, the British Council opened its doors in 1934. Also the German Goethe Institut opened in 1951, following the experience of the former Deutsche Akademie. Its purpose has always been to give a comprehensive image of Germany by providing information on its cultural, social and political life. So far it has forged a strong network of around one hundred centres.

Currently there are more being more than thirty centres, which among them all provide around 3,500 offices settled in more than 150 countries.

\section{The role of Libraries in international cultural centres abroad}

The origins of the opening of international cultural libraries can be traced back to the Nineteenth century, when several countries opened librarian spaces dedicated exclusively to their citizens living in remote areas, generally colonies or former colonies. 
However, those institutions restricted their access to certain races and ethnic origins (Coleman, 2008). So happened with the Penang Library in Malaysia established in 1819, the General Library of the Institute of J amaica established in 1879 and the Lagos Library in Nigeria, founded in 1932. In these cases and others, the libraries were key for the intellectual development of the native elite, as well as a weapon to fight illiteracy in the colony.

Libraries in cultural centres abroad are among the most frequented, prominent and visible areas inside cultural venues (Prieto, 2015). They offer a complete range of services not only for foreign language students or citizens interested on the country's culture, but also for those with a wide and general range of interests ranging from digital literacy, general information on cooperation programs and scholarships to simply connect to the Internet.

As the cultural centres libraries are open to the general public with little to none restriction they are perceived by many local citizens as public libraries. The impact of public libraries in society has been extensively studied in the literature of library and information sciences. (See, f.i., Suaiden:2002).

Public libraries adapt and plan their offers and services according to the needs and specific characteristics of their community, but they all share a series of common features such as:

- A reading room to consult documents and information

- A service of specialized bibliographic information

- Inter-library loan

- Document retrieval

- Online access to automated catalogues

- Internet access

- Reading activities and contests

- Services of formation on digital literacy as well as on document and information retrieval. 
Harris (1998) and Aabo (2005) identify how public libraries mean great benefits and opportunities for citizens, in its multiple forms, shapes and sizes, in the vicinity of homes, or rather immersed in the community or a locality.

Positive consequences of these libraries do not only reach the core of their frequent users, such as second language students. Libraries do also serve to the whole population where they are placed, as citizens everywhere show needs that might me fulfilled by these libraries. Cultural centre libraries programming is developed for every social group with no limitations of age, economic level, education, gender or race.

The social, educational and financial benefits offered by a library are undeniable (Holt, Elliott and Moore, 1999; IFLA, 1994). They are vital, in many cases, for the development of the community: they provide access to the outside world, even suppress borders in some communities or countries with restrictions on the access to information (Keohane and Nye, 1998; Lynch and Preston, 1990). As Arms (2000), Rogers and Freiberg (1969) observed, having access to libraries and their documents is a manifestation of freedom of expression, information and consultation of documentary material from many parts of the world, whether in physical or online format.

The environments of libraries, in most cases, are pleasant, enjoyable and productive, enabling users to obtain their inquiries in a short period of time. This experience is even more grateful when the staff attending the space is well trained and informed.

It is also worth mentioning that since the late 80 's, computers were introduced to libraries. Those located within cultural centres are no exception, and they provide access to Internet and other electronic sources, as well as mobile media support .

Users of those library centres can be divided into three categories:

- Foreign language or cultures students, which access the documents provided by the libraries to improve or deepen their learning experience.

- Immigrants or expats, which use the cultural centre as a meeting point and as a way to feel close to their homeland.

- General public which benefits from the services and activities provided to the local community. 
Kerslake and Kinnel (1997) indicated that entering the library of a cultural centre allows access to the outside world, to information the user wants to view, and it does so in an unrestricted and anonymous way. According to these authors, the mentioned features are essential for freedom of expression and the development of people. So, libraries are vital to ensure these rights.

There is a huge variety of workers at cultural centres. There are no common hiring policies or human resources categories at the thirty analyzed centres and their more than 2.200 libraries. So, in order to understand this department, difference should be made among expats (that is, professionals born and raised in the centre's country of origin) staff and local employees (professionals born in the country where the centre library is placed). Management positions are usually taken by the former.

The expat employee can be found in those cultural centres which deploy a real professional library network organized from their mother centre. This is the case of Institut Française, Goethe Institut, Cervantes Institute, Italian Cultural Centre, Korean Cultural Centre and Instituto Camoes. The remaining centres do not follow a quota for expats citizens, hiring local workers by the local regulation of the nation or state where it is placed.

In the first type of centres, the number of workers in each library is set up by its network according to criteria of local demand, size, number of users, documents, services, etc. Funding is provided by the mother centre. The remaining category of libraries is supported directly by each centre. The corresponding managing department assigns resources and personnel but the final decision falls ultimately on each Institution director, given that this Director approves the general budget.

Most of the librarians from the thirty analyzed centres are specialised on library and information sciences. Minimum knowledge and competences on social and human culture of the city where the centre is located are also valued. In this sense, all the staff must speak the cultural centre language and be familiar to its culture.

Foretelling the future expansion or restructuration of libraries is impossible. Yet, given that they are a service depending on the cultural centres, their development is narrowly linked to the very own institutes. The global economic crisis has reduced budgets of the Ministries of Culture and Foreign Relations on almost every nation, which led to stop expansion plans and even moving or closing centres. 
The few new inaugurations have followed basically diplomatic and trade reasons. That is the case of the new openings in the Persian Gulf area and Southestern Asia. Other cases seek offering assistance to local communities, as happens in India, some African countries and Latin America. The context of former colonies explain this situations, as happens with the new centres of British Council and Alliance Française.

\section{Activities Developed in Libraries}

Libraries located in cultural centres abroad host various activities, as they display many other features, focused directly to the local community. The services offered are extensive, as they are open facilities in many cases. They are also presented as community's social spaces where people can participate, to discuss and debate mainly about culture and everyday subjects, while participating in educational activities and training sessions to preserve traditions, etc. Libraries can also be considered a valuable resource for cooperation and collaboration. To achieve these goals they go beyond their physical building to help or reach out people, as it will be discussed later.

In this regard, Hiraldo and Buyol (2001) make an adequate distinction of mainly two categories of libraries, in function of the activities they offer. On one side, we find those centres where their main function is to support teaching and dissemination of the language and, on the other side, those libraries that offer other activities, usually on the social, educational and cooperative fields of which local citizens are the greatest beneficiaries. That is why the resources and aids that the latter offer are very valuable for their users, with special attention to those belonging to excluded groups, ethnic minorities, or people with economic needs, among others.

As we have commented above, generally libraries offer a wide range of activities that are parallel to their traditional services. Some of them are:

- The possibility or ease to publish or edit a document

- The assistance for travel to the native country's cultural centre, which opens the possibility of free training in various professional sectors

- Professional advice and networking proposals (which also builds a connection among scientists)

- Information for international job researchers and funding in their respective country, as well as discussions on science and sustainability issues,

- Invite or present the works or creations of local citizens 
- International promotion

- Donation programs to buy documents, research, etc.

Also thanks to new technologies and tools or applications such as social networking sites, libraries can play an important role in helping the local community in case of emergencies, natural or ethnic disasters, among others, by helping and offering support on locating relatives, friends or aiding in their search, etc, thus offering an unquestionable benefit in areas that lack an advanced technology infrastructure.

It would be impossible to collect an exhaustive list of services offered by these institutes given that some of them are more than 100 year old. Yet, a list of the most representative examples from recent years is listed below, as it provides another indicator for evaluating the importance of these activities:

The United States created during the last century a strong library network consisting of about two hundred spaces. Sussaman (1973) described this network which was managed by the United States Information Agency (USIA). It existed from 1953 to 1999, when they disappeared to be merged into other embassies services. Along with these, various programs and activities were adopted as a tool of cultural diplomacy (Robbins, 2001), to make possible the publication of some 3,000 titles in languages such as Arabic, Urdu, Bengali, Indonesian, and Portuguese (Robbins, 2007). Another example was the Indo-American programs, very active for decades, generating personnel exchange experiences, workshop organization, sponsored education programs, among others (Konnur, 1990).

In other sense Bridging Voices, a grant program from the British Council, is aimed at promoting an improved understanding of the role that religion plays in both international affairs and the formulation of foreign policies, by supporting transatlantic academic and policy dialogues and accompanying outreach activities.

As for the case of Korea, it has developed an strategy focusing on sensitive and experiential activites. The Korean Cultural Centre has been established in many countries so that visitors are able to get involved in diverse aspects of Korean culture in the world. Everyone is given an opportunity to learn more about Korea, as well as experience the charm of Korean culture, also in the online spaces where lots of information is provided.

Another good example is China. The nearly 450 Confucius Institutes develop innovative programs to promote and support China related activities. They do so through a 
multidisciplinary approach that means that they engage academically and professionally with students and scholars from a range of backgrounds, and collaborate on implementing activities and projects to strengthen ties with their partners. Their unique research has strengths through collaboration in the areas of science, engineering, business and law that enhance Chinese academic leadership role in the Asia Pacific region. The libraries of many of these centres, by being physically located in academic centres, serve as a tool to develop these objectives.

Libraries from Instituto Camões organize events to present books from lusophone authors, endorses collaboration projects with local Universities and foster activities to encourage children's reading and writing habits. Sometimes they offer the diplomatic pouch to send and move art pieces to exhibits in foreign countries. They also organise a grant program on summer courses about Portuguese language and culture developed in Portuguese universities or other institutions recognised by the same Instituto Camões.

The French government-led multimedia libraries network is a real public diplomacy tool which offers a wide range of collaboration actions with local authorities. Many of these actions are billateral. It should be remarked the help provided to social groups in need. Actions developed in Tunisia during the last years are specially worth mentioning. They address to issues such as formation in community life, environmental awareness, support to women in danger or financial support to microcredits for Tunisians coming back from Libia due to tensions in the country. Special attention must be paid also to specific formation programmes carried by France 24 and the French International television network addressed to Tunisian public television and radio journalists. In conclusion, French cultural centres and their libraries seek to encourage the development of associations and the circulation and debate of ideas to get closer to civil society.

Another popular service during the last years is the Culturethèque platform, a huge digital library which allows remote access from any foreign country to different kinds of content: literature, news, cinema, music... This digital content is provided by many associated institutions such as French National Audiovisual Institute (INA), Gallica, French National Library (BNF), International Philosophy College, Shoah Memorial or Universcience.

Goethe Institut libraries offer a funding programme for translating German books into other languages. This program tries to grant easier access to German contemporary 
literature, children and youth literature, scholarly and non-fiction works for nonGerman speaking public. The centres work jointly with other local libraries and professional associations to encourage professional dialogue and interchange. Some concrete examples could be: the puppet festival organisation on 2016 at Mandalay, Myanmar; the edition in 2014 of a book with 600 pictures of the coast city of Danang, Vietnam; a photo exhibit in Laos, Nigeria, to connect professionals form different industrial sectors, etc.

The J apan Foundation, in a similar way, develops a wide number of different initiatives ranging from afforestation activities taking place in Malaysia since 1995 to cinema festivals such as the Istambul J apanese Film Festival or the J apanese Film Festival in Cambodia. Also, in 2013, in the Philippines, after Yolanda Typhoon, the Japan Foundation Centre organised a series of conferences to educate citizens about the issue.

Libraries of the Russian Cultural Centre, spread through more than eighty countries, also organise activities deeply implied with local communities. Several of those actions can be remarked as the case of summer camps in Kazakhstan. Free concerts were organised in Cairo impoverished areas. In New Delhi, e-books and other multimedia material are offered to any citizen wishing to study Russian language. It is worth mentioning that after the USSR collapse the publishing of Russian science was suspended in India. Nowadays, one of the main Russian publishers, Progress and Rainbow, is currently translating fiction and scientific works into 13 Indian languages. Several Russian journals are being published in Indian languages, reaching more than two million subscribers.

And the examples go on in more than thirty institutions listed in detail below.

\section{How Libraries in Cultural Centres are Organized}

Once the context of the presence of libraries, their actions and some of the functions and activities that they fulfill are defined, we indicated on Table 1 the enumeration and description of diverse institutions, with the aim of knowing their name and country of procedence of their respective cultural centres, their number of offices and libraries available in each one of them, as well as their kind of administration. 
As mentioned above, currently libraries from cultural centres abroad do not have their own classification, either defined or accepted by professional associations or organizations, as they present a duality.

On one side, they tend to be perceived as public libraries in most cases (offering many support services and aid to local citizens) and on the other side, they are managed and maintained either by the respective Ministries of Foreign Affairs or diplomatic missions established in the country, or by private non-profit organizations such as partnerships, trusts or foundations, among others, of foreign or minority cultural groups in the country or target area.

Anyway this classification may serve as stimulus for future research in which it may be necessary to know the total libraries available, their locations, administration, services, etc.

The following table summarizes the most important cultural centres abroad and their libraries. It includes 30 institutions, selecting the ones with most tradition, the oldest, those who have more headquarters around the world, and those with a great diplomatic reputation and networking capacity.

Table 1: List of libraries in cultural centres abroad

\begin{tabular}{|c|c|c|c|c|}
\hline & $\begin{array}{r}\text { Cultural } \\
\text { Centres } \\
\text { Abroad } \\
\end{array}$ & $\begin{array}{r}\text { Number } \\
\text { of libraries }\end{array}$ & $\begin{array}{r}\text { Library } \\
\text { management } \\
\text { system }\end{array}$ & $\begin{array}{r}\text { Budget } \\
\text { management }\end{array}$ \\
\hline Instituto Camoes (1992) & 18 & 15 & Network & Public - Lisbon \\
\hline British Council (1934) & 200 & 15 & Network & Public - London \\
\hline Alliance Française (1883) & 1073 & 1073 & Unconnected & Private \\
\hline Institut Française (1907) & 144 & 143 & Network & Public - Paris \\
\hline Goethe Institut (1951) & 160 & 96 & Network & Public - Berlin \\
\hline Cervantes Institute (1991) & 83 & 63 & Network & Public - Madrid \\
\hline Confucius Institute (2004) & 443 & unknown & Unconnected & $\begin{array}{r}\text { Public - Beijing } \\
\text { / Private }\end{array}$ \\
\hline Confucius Classroom (2004) & 648 & unknown & Unconnected & $\begin{array}{r}\text { Public - Beijing } \\
\text { / Private }\end{array}$ \\
\hline J apan Foundation (1972) & 22 & 21 & Network & $\begin{array}{r}\text { Public-Tokio / } \\
\text { Private partnership }\end{array}$ \\
\hline Russian Cultural Centre (1990) & 88 & 80 & Network & $\begin{array}{r}\text { Public - Moscow/ } \\
\text { Private partnership }\end{array}$ \\
\hline Italian Cultural Centre (1926) & 90 & 90 & Unconnected & Public-Roma \\
\hline Societa dante Alighieri (1889) & 518 & 400 & Unconnected & Private \\
\hline
\end{tabular}




\begin{tabular}{|c|c|c|c|c|}
\hline Korean Cultural Centre (2009) & 22 & 22 & \multicolumn{2}{|c|}{ NetworkPublic - South Korea } \\
\hline Indian Cultural Centre (1950) & 35 & 35 & Network & Public - Delhi \\
\hline Iexican Cultural Institute (1972) & 14 & 14 & Unconnected & $\begin{array}{l}\text { Public- Mexico DF } \\
\text { Private partnership }\end{array}$ \\
\hline $\begin{array}{r}\text { Arab Cultural } \\
\text { Community Centre (1973) }\end{array}$ & 1 & 1 & Unconnected & Private partnership \\
\hline Israel Cultural Centre & 1 & 1 & Unconnected & Public - Tel Aviv \\
\hline Irish Cultural Centre (1989) & 4 & 4 & Unconnected & Public/ Private \\
\hline Turkish Cultural Centre & 12 & 12 & Unconnected & Private partnership \\
\hline $\begin{array}{r}\text { Austrian Cultural } \\
\text { Forum Institute (1942) }\end{array}$ & 29 & 29 & Unconnected & Public / Viena \\
\hline plynesian Cultural Centre (1963) & 7 & 7 & Unconnected & Private partnership \\
\hline pmanian Cultural Centre (2003) & 19 & 19 & Unconnected & Embassy of Romania \\
\hline Czech Centre (1986) & 25 & 25 & Unconnected & Public - Prague \\
\hline Danish Cultural Institute (1940) & 8 & 8 & Unconnected & $\begin{array}{r}\text { Euspices by Danish } \\
\text { Ministry of Culture } \\
\text { / Private }\end{array}$ \\
\hline dinavian Cultural Centre (1968) & 5 & 5 & Unconnected & Private partnership \\
\hline enic Cultural Foundation (1992) & 6 & 6 & Unconnected & $\begin{array}{r}\text { e Cultural Section of } \\
\text { the Greek Embassy }\end{array}$ \\
\hline Balassi Institute (1927) & 22 & 22 & Unconnected & Embassy \\
\hline Eesti Instituut (1989) & 2 & 2 & Unconnected & Ministry of Culture \\
\hline \begin{tabular}{|ll} 
The & Finnish Culture and \\
& Academic \\
& $(2005)$
\end{tabular} & 17 & 16 & Unconnected & $\begin{array}{r}\text { Tinistry of Education } \\
\text { in Finland - Private } \\
\text { partnership }\end{array}$ \\
\hline$\underset{\text { (1991) }}{\text { Brazilian Cultural }}$ Centre & 29 & 29 & Unconnected & $\begin{array}{l}\text { Brazilian } \\
\text { diplomatic missions }\end{array}$ \\
\hline TOTAL & 3.745 & 2.253 & & \\
\hline
\end{tabular}

The information provided has been compiled through the responses given in the questionnaires sent to the centres in most cases, and checking documents like statistical yearbooks in their websites. 


\section{Conclusion}

In sum, libraries for cultural centres abroad are a valued service wherever they are located. Undoubtedly, their respective cultures are very visible, as well as its ideas, lines of work and objectives, set many times by their respective country State Administration, as all of them represent a vital assistance to local citizens by offering multiple services inside and outside their premises, which sometimes fill a gap on the features offered by local libraries.

Due to the service they provide and the needs they meet, it becomes vital to extend the recognition of libraries on a global scale. To achieve this, it is necessary to include in professional organizations, specific committees or working groups that are focused on this type of centres. For example, in the field of libraries, the IFLA (International Federation of Library Associations and Institutions) should create a commission including the more than 2,200 libraries depending on cultural centres abroad.

Working together would increase cooperation among the group's companies by making proposals of social natures and even policies based on common principles for the people's benefit. Today, information technology and communication encourage the exchange of common points of agreement, thus allowing for increased bilateral and multilateral relations, and even reduce costs.

All these activities should be foreseen by policy makers, as well as of those centres managed by the Ministries of Foreign Affairs, and not only to prevent the closure of libraries, as it has happened in the British Council, but to rather open more libraries and increase their budgetary allocations.

\section{References}

- Aabø, S. (2005). The role and value of public libraries in the age of digital technologies. J ournal of Librarianship and Information Science, 37(4), 205-211.

- Arms, W. Y. (2000). Digital libraries. MIT press.

- Coleman Jr, S. J. (2008). Empire of the Mind: Subscription Libraries, Literacy \& Acculturation in the Colonies of the British Empire. ProQuest.

- Cortier, C. (1998). Institution de l'Alliance française et émergence de la francophonie: politiques linguistiques et éducatives: 1880-1914 (Doctoral dissertation, Lyon 2). 
- Harris, K. (1998). Open to interpretation: community perceptions of the social benefits of public libraries. London: Community Development Foundation.

- Hiraldo, R. A., \& Pujol, J. B. (2001). International Cultural Exchange through Libraries. International Librarianship: Cooperation and Collaboration.

- Holt, G. E., Elliott, D., \& Moore, A. (1999). Placing a value on public library services. PUBLIC LIBRARIES-CHICAGO-PUBLIC LIBRARY ASSOCIATION-,38, 98-109.

- IFLA (1994). IFLA / UNESCO Public Library.

- Keohane, R. O., \& Nye, J. S. (1998). Power and interdependence in the information age. FOREIGN AFFAIRS-NEW YORK-, 77, 81-94.

- Kerslake, E. and Kinnel, M. (1997) The Social Impact of Public Libraries: A Literary Review. Boston Spa: British Library Innovation Centre (Report No. 85).

- Konnur, M. B. (1990). Transnational Library Relations: The Indo-American Experience (Vol. 10). Concept Publishing Company.

- Lynch, C. A., \& Preston, C. M. (1990). Internet access to information resources. Annual review of information science and technology, 25, 263-312.

- Melissen, J . (2005). Wielding soft power: the new public diplomacy. Netherlands Institute of International Relations' Clingendael'.

- Niño, A. (2014). La Guerra Fría cultural en América Latina. Desafíos y límites para una nueva mirada de las relaciones interamericanas. Revista Complutense de Historia de América, 39, 329-333.

- Prieto, J . J . (2015). World Libraries, the Diplomatic Role of Cultural Agencies. European Review, 23 (03), 361-368.

- Robbins, L. S. (2001). The overseas libraries controversy and The Freedom to Read: U.S. librarians and publishers confront Senator J oseph McCarthy. Libraries \& Culture, 36(1).

- Robbins, L. S. (2007). Publishing American Values: The Franklin Book Programs as Cold War Cultural Diplomacy. Library Trends, 55(3), 638-650.

- Rogers, C. R., \& Freiberg, H. J . (1969). Freedom to learn.

- Suaiden, E. J. (2002). El impacto social de las bibliotecas públicas. Anales de Documentación, N. 5, 2002, 333-344

- Sussman, J. (1973). United States Information Service Libraries. Occasional papers (University of Illinois at Urbana-Champaign. Graduate School of Library Science); no. 111. 